\title{
Predictive values of serum amyloid-A and CRP for infection in febrile neutropenic cancer patients
}

\author{
Ayşe Batırel' ${ }^{1}$ Serap Gencer ${ }^{1}$, Serdar Özer ${ }^{1}$, Taflan Salepci \\ ${ }^{1}$ Department of Infectious Diseases and Clinical Microbiology, Kartal Dr. Lutfi Kirdar Training and Research Hospital, \\ Istanbul, Turkey \\ ${ }^{2}$ Department of Medical Oncology, Gaziosmanpaşa Hospital and Onko Tip Merkezi, Istanbul, Turkey
}

\begin{abstract}
Objectives: To evaluate predictive values of serum amyloid A (SAA) and C-reactive protein (CRP) for infection and mortality in patients with febrile neutropenia (FEN).

Methods: Daily measurement of serum SAA and CRP levels of patients during antibiotherapy for FEN.

Results: Sixty-five FEN episodes of 52 patients were evaluated. Median CRP and SAA levels on 1st day of FEN were 137 $\mathrm{mg} / \mathrm{L}(23-420 \mathrm{mg} / \mathrm{L})$ and $547 \mathrm{mg} / \mathrm{L}(11-1660 \mathrm{mg} / \mathrm{L})$, respectively. For detection of infection of infection the sensitivity, positive predictive value (PPV), and negative predictive value (NPV) of SAA at a level of $>80 \mathrm{mg} / \mathrm{L}$ were as $100 \%, 48 \%$ and $100 \%$. Whilethe sensitivity, PPV, and NPV of CRP at a level of $>50 \mathrm{mg} / \mathrm{L}$ were as $86 \%, 47 \%$ and $60 \%$, respectively. Predictive values of initial SAA and CRP levels for infection didn't differ significantly (CRP: $p=0.24$, SAA: $p=0.39$ ). SAA and CRP levels on the last day of FEN course were significant for infection and mortality (for infection: $p=0.003$ for CRP and $p=0.026$ for SAA; for mortality: $p<0.001$ for CRP and $p=0.021$ for SAA). Both initial and daily SAA and CRP levels correlated with each other positively and statistically significantly $(p<0.001)$. The area under the curve (AUC) on the receiver operating character (ROC) curve for CRP and SAA were $0.72(p=0.003,95 \% \mathrm{Cl}: 0.59-0.86)$ and $0.68(p=0.19,95 \%$ Cl: 0.54-0.82), respectively.
\end{abstract}

Conclusions: Despite low predictive values in decision of initial therapy, these parameters would be helpful in decision of modification and evaluation of response to therapy. J Microbiol Infect Dis 2014; 4(4): 128-135

Key words: Fever, neutropenia, febrile neutropenia, C-reactive protein, serum amyloid A

\section{Febril nötropenik kanser hastalarında serum amiloid-A and C-reaktif protein CRP'nin enfeksiyon için öngörü değeri}

\section{ÖZET}

Amaç: Febril nötropeni (FEN)si olan hastalarda serum amyloid A (SAA) ve C-reaktif protein (CRP)'in enfeksiyonun erken tanısı ve mortaliteyi öngörmede değerini incelemek

Yöntemler: Antibiyoterapi sırasında hastaların serum SAA ve CRP düzeyleri günlük olarak ölçüldü.

Bulgular: Elli-iki hastanın $65 \mathrm{FEN}$ atağı incelendi. FEN tablosunun ilk günündeki medyan CRP ve SAA değerleri sırasıyla $137 \mathrm{mg} / \mathrm{L}$ (23-420 mg/L) ve $547 \mathrm{mg} / \mathrm{L}$ (11-1660 mg/L) idi. Enfeksiyonun tespitinde $80 \mathrm{mg} / \mathrm{L}$ üzerindeki SAA düzeyinin duyarlıı̆ı 100\%, pozitif prediktif değeri (PPD) ve negatif (NPD) prediktif değerleri sırasıyla \%48 ve \%100 idi. Enfeksiyonun tespitinde $50 \mathrm{mg} / \mathrm{L}$ üzerindeki CRP düzeyinin duyarlıı̆̆ \%86, PPD ve NPD sırasıyla \%47 ve \%60 idi. Başlangıç SAA ve CRP düzeyleri arasında infeksiyonu öngörmede anlamlı fark saptanmadı (CRP için $p=0,24$, SAA için $p=0,39$ ). Ayrıca, febril atağın ilk gününden onikinci gününe kadarki günlük medyan SAA ve CRP değerleri arasında istatistiksel anlamlı bir korelasyon vardı $(p<0,05)$. İzlemin son günündeki SAA ve CRP düzeyleri enfeksiyon ve mortalite açısından anlamlıydı (enfeksiyon varlığında CRP için $p=0.003$, SAA için $p=0,026$; mortalite varlığında CRP için $p<0,001$ ve SAA için $p=0,021)$. Hem başlangıç hem de günlük ölçülen SAA ve CRP değerleri birbirleriyle pozitif ve anlamlı korelasyon gösterdi $(p<0.001)$. CRP ve SAA için ROC eğrisi altındaki alan sırasıyla 0,72 ( $p=0,003$, \%95 GA: 0,59-0,86) ve 0.68 ( $p=0,019$, \%95 GA: 0,54-0,82) idi.

Sonuç: Başlangıç tedavi kararında öngörü değerleri düşük olmasına rağmen, bu parametreler tedavide değişiklik kararının alınmasında ve tedaviye yanıın değerlendirilmesinde yararlı olabilir.

Anahtar kelimeler: Ateş, nötropeni, febril nötropeni, C-reaktif protein, serum amyloid A

Correspondence: Ayşe Batırel, Kartal Dr. Lütfi Kırdar Education and Research Hospital,

Infectious Diseases and Clinical Microbiology, Kartal - İstanbul, Turkey Email: aysebatirel@yahoo.com

Received: 27 July 2014, Accepted: 17 September 2014

Copyright (C) Journal of Microbiology and Infectious Diseases 2014, All rights reserved 


\section{INTRODUCTION}

In spite of advantages in prophylactic and empirical antimicrobial therapy, unrecognised or ineffectively treated infections are common causes of death in patients with prolonged chemotherapy-induced neutropenia. The diagnosis of neutropenic infection is difficult. Inadequate presentation of clinical and radiological signs of neutropenic infections may delay the diagnosis of life-threatening infections. ${ }^{1,2}$ Fever in a neutropenic patient may be the first and the only sign of infection. Because of that, immediate empirical broad-spectrum antibiotherapy has become a common practice in the management of patients with febrile neutropenia (FEN). ${ }^{3}$ Moreover, this approach may result in both ineffective treatment in some patients and overtreatment in others. As a matter of fact, microbiologically or clinically defined infections have been documented in only $60 \%$ of cases. Therefore, reliable parameters are necessary for description of infections causing FEN. ${ }^{4}$ Serum and plasma concentrations of mediators related to infection such as acute phase reactants or cytokines are thought to reflect the presence of microbial pathogens. The determination of such mediators may support the early diagnosis of infections. Therefore, highly specific and sensitive markers indicating infection early in the course are being investigated. ${ }^{5-8}$ Concentrations of several acute-phase proteins [C-reactive protein (CRP), serum amyloid $A(S A A)$, procalcitonin], proinflammatory cytokines [tumor-necrosis factor-alpha (TNF- $\alpha$ ), interleukin (IL)-1, IL-6, IL-8, interferon (IFN)- $\gamma$ ] and soluble adhesion molecules (intercellular adhesion molecule 1, vascular cell adhesion molecule 1 , soluble E-selectin) in the serum have been investigated for their contribution to identify the infectious cause of FEN. However, data regarding the significance of proinflammatory cytokines, CRP, and soluble adhesion molecules in the clinical evaluation of FEN is quite limited in the medical literature. Furthermore, the predictive values of those parameters for decision of initial antimicrobial therapy in patients with FEN is quite low. Also, they had limited value to predict outcome in cancer patients. ${ }^{9,10}$

Elevated CRP has been reported to be a predictor of lower survival rates after surgical resection in patients with malignancy (eg: lung, gastrointestinal, urinary and genital tract cancers). It may serve as a prognostic predictor for survival and posttreatment monitoring in cancer patients. ${ }^{11,12}$ SAA, an acute-phase protein synthesized predominantly by liver, may rise up to 1000 -fold during acute inflammation. It has been shown to activate the inflamma- tory pathway, and may have a role in immunomodulation. ${ }^{13} \mathrm{SAA}$ is found to be more sensitive than CRP for the indication of some of advanced cancers. ${ }^{14}$

In one of our previous studies in which we investigated various risk factors in febrile neutropenic patients, we had found that the CRP levels in the first 48 hours of FEN episode were significant for prediction of infection $(p=0.001)$ but insignificant for prediction of mortality $(p=0.595) .15$ In this prospective study, we intended to evaluate the value of mainly SAA for earlier prediction of infection and mortality, and its correlation with CRP.

\section{METHODS}

Patients. Adult cancer patients with FEN who were followed and treated in the Medical Oncology and the Radiation Oncology departments of Kartal Dr. Lütfi Kırdar Training and Research Hospital, were hospitalized in the Infectious Diseases Department. We enrolled 65 FEN episodes of a total of 52 patients of ages between 15 and 77 in a prospective study for a year. Written informed consent of the patients was obtained before enrolment. FEN is defined as a single oral temperature of $\geq 38.3^{\circ} \mathrm{C}$ or $\geq 38^{\circ} \mathrm{C}$ lasting for $\geq 1 \mathrm{~h}$ within 24 hours in patients with absolute neutrophil count (ANC) $\leq 500 / \mathrm{mm}^{3}$ or between 500 and $1000 / \mathrm{mm}^{3}$ and expected to decrease within 24-48 hours in absence of blood or blood product transfusion or cytotoxic therapy. ${ }^{3}$ Patients having ANC never $<500 / \mathrm{mm}^{3}$ and neutropenia without fever and those having fever related to transfusion of blood or blood products were excluded.

Initial evaluation of patients with FEN included a complete medical history, thorough physical examination (involving skin, oropharynx, perianal region and catheter-entry sites) and various laboratory tests. At least two blood specimens 30 minutes apart, urine and specimens from other appropriate body sites suspected to be the focus of infection according to signs and symptoms were obtained immediately for culture and urgent empirical antimicrobial therapy was started. Blood cultures were performed in an automated system (BacTec, Becton-Dickinson, USA). Measurement of complete blood count, CRP, SAA, erythrocyte sedimentation rate (ESR), standard blood chemistry, a complete urine analysis and chest radiography were made within $24 \mathrm{~h}$ of the onset of fever. Additional necessary measurements and cultures were done during the study period. Blood samples for complete blood count, CRP and SAA were obtained daily until the end of the antibiotherapy. 


\section{FEN episodes were divided into the following 4 categories, according to the clinical and microbiological findings:}

1: Microbiologically-documented bacteremic infection (growth in blood cultures which would explain the cause of fever) (BI)

2: Microbiologically-documented non-bacteremic infection (a positive result of cultures of samples other than blood which would explain the cause of fever) (MI)

3: Clinically-suspected infection without any evidence microbiologically (clinical, physical or radiological findings compatible with infection, but without any microbiological proof) (Cl)

4: Fever of unknown origin (FUO) (no clinically-suspected or microbiologically- documented infection)

The following characteristics of the patients and/or episodes were recorded: age, sex, type of malignity, Karnofsky performance status, ${ }^{16,17}$ body temperature and polymorhonuclear leukocyte (PNL) counts at the beginning of episode, presence of high risk factors, previous FEN episode, presence of comorbidities (pneumonia, diarrhea, severe mucositis, hypotension, cardiopulmonary insufficiency and/or any organ dysfunction) and complications during follow-up, use of colony-stimulating factor, transfusion of blood or blood products, duration of fever, duration of neutropenia, duration of antibiotherapy and response to empirical therapy.

The characteristics of high-risk group patients were defined as the following: presence of a hematological malignancy (lymphoma or acute leukemia), pneumonia, diarrhea severe mucositis, hypotension, cardiopulmonary insufficiency, or any organ dysfunction, neutropenia lasting $\geq 10$ days and neutrophil count $\leq 100 / \mathrm{mm}^{3}$, poor general appearance. Whereas, the characteristics of low-risk group patients were: neutropenia lasting $<10$ days, polymorhonuclear leukocyte count $>100 / \mathrm{mm}^{3}$, platelet count $>75.000 / \mathrm{mm}^{3}$ and good general appearance. $^{3}$

Empirically a b-lactam antibiotic with anti-pseudomonal activity (ceftazidime $2 \mathrm{~g}$ three times a day IV, piperacillin-tazobactam $4.5 \mathrm{~g}$ three times a day IV or cefepime $2 \mathrm{~g}$ twice a day IV or cefoperazonesulbactam $2 \mathrm{~g}$ twice a day) was administered initially. The initial empirical antibiotic therapy was chosen by of the admitting physician. Antimicrobial therapy was modified as needed when the infection was documented microbiologically or in case of persistance of fever. Antibiotherapy was discontinued after the patient had been afebrile for five days, at the time of neutrophil recovery $\left(\mathrm{ANC}>500 / \mathrm{mm}^{3}\right)$ or after the signs of infection disappeared. Antifungal and/or antibacterial prophylaxis were not given to the patients.

Definition of a new FEN episode. Development of a new episode of FEN in a patient who had already recovered from a previous episode of FEN, had completed antimicrobial therapy and had received another cycle of chemotherapy and/or radiotherapy which caused neutropenia again.

Measurement of CRP. N High Sensitivity CRP (BN TM System, Dade Behring) was used. The upper limit of the normal range of CRP was $\leq 3 \mathrm{mg} / \mathrm{L}$.

Measurement of SAA. N Latex SAA (Behring Nephelometer II, Dade Behring) was used. The upper limit of the normal range of SAA was $6.4 \mathrm{mg} / \mathrm{L}$.

Ethical Statement/Approval. This study was approved by the Institutional Review Board of Kartal Dr. Lütfi Kırdar Training and Research Hospital.

Statistical Analyses. SPSS 17.0 Software (Chicago,IL.,USA) was used for the statistical analyses. Frequency of categorical variables; the median, standard deviation, minimum and maximum values of quantitative variables were determined. The appropriateness of quantitative variables to normal distribution was tested one by one by OneSample Kolmogorov-Smirnov Test. Spearman's Rank Correlation Test was used to describe the correlation between quantitative variables (fever, CRP, SAA etc.). Wilcoxon's Signed Rank Test was used for the statistical significance level of median values of CRP ve SAA. Sensitivities, specificities, positive and negative predictive values of CRP and SAA for detection of infection were calculated. The predictive values of the first and the last day CRP ve SAA levels were tested for mortality and for category of infection by Mann-Whitney $U$ Test and by Kruskal-Wallis Variance Analysis respectively. For description of CRP and SAA levels on consecutive days, Friedman's Test was used. Receiver operating characteristic (ROC) curve and area under the curve (AUC) were used to determine the accuracy of CRP and SAA in predicting infection.

\section{RESULTS}

We evaluated 65 FEN episodes of 52 patients covered by FEN protocol during one-year period. The median age of 52 patients ( 33 men and 19 women) was 52 years. The distribution of types of underlying malignancies of the patients is shown in Table 1. All 
neutropenic episodes were caused by given chemotherapy. Fifty-two (80\%) of FEN episodes were the first episode, the other $13(20 \%)$ had previous episodes. While colony-stimulating factors were given in only $4(6.2 \%)$ episodes, blood or blood products were transfused in 31 (47.7\%) episodes.

Table 1. Types of malignancies of the patients $(n=52)$ with febrile neutropenia

\begin{tabular}{lc}
\hline Diagnosis of Malignity & $\mathrm{N}(\%)$ \\
\hline Non-Hodgkin Lymphoma & $12(23)$ \\
Gastric Cancer & $6(11.5)$ \\
Lung Cancer & $6(11.5)$ \\
Head and Neck Cancer & $5(9.6)$ \\
Colon/Rectal Cancer & $5(9.6)$ \\
Breast Cancer & $3(5.8)$ \\
Hodgkin Lymphoma & $2(3.8)$ \\
Ovarian Cancer & $2(3.8)$ \\
Endometrial Cancer & $2(3.8)$ \\
Sarcoma & $2(3.8)$ \\
Others* & $7(13.4)$ \\
\hline
\end{tabular}

*Others: Acute Lymphocytic Leukemia, Rhabdomyosarcoma Pancreas, Testis, Prostate and skeletal cancer

Accompanying comorbidity (eg: Diabetes mellitus, chronic renal failure, chronic obstructive pulmonary disease etc.) was present in $26(40 \%)$ febrile episodes. Only six (11.5\%) patients were in high-risk group, while the rest was in low-risk group. There were no patients with invasive aspergillosis (IA) based on clinical and radiological findings. Fiftysix $(86.2 \%)$ episodes were cured without any complications. While $4(6.2 \%)$ febrile episodes resulted in cure with complications (respiratory insufficiency, transfer to intensive care unit, confusion/ change in mental status, bleeding requiring transfusion, arrythmia requiring treatment, renal insufficiency, allergic reaction or fungal infection), 5 patients died during the course of therapy. Four of them died decause of severe sepsis and 1 because of possible progression of underlying malignancy.

Out of a total 26 infections, 23 were microbiologically and three were clinically defined, mortality was seen in only five cases. Of the total 65 episodes, $16(24.6 \%)$ had BI (six Staphylococcus aureus, three Streptococcus pneumoniae, two Pseudomonas spp., two Klebsiella spp., one Acinetobacter spp., one Enterobacter aerogenes, one Escherichia coli), seven (10.8\%) had Ml (two S. aureus, two
E. coli, two Klebsiella spp. and one Pseudomonas spp.), three $\mathrm{Cl}(4.6 \%)$ and 39 (60\%) had FUO.

The median duration of fever was 3 days (114 days). The median duration of neutropenia was 4 days (1-9 days). The median duration of antibiotherapy was 8 days (1-14 days). The median CRP level at the beginning was $137 \mathrm{mg} / \mathrm{L}$ (range: 23 $420 \mathrm{mg} / \mathrm{L}$ ) and the median SAA level was $547 \mathrm{mg} / \mathrm{L}$ (range: 11 - $1660 \mathrm{mg} / \mathrm{L}$ ).

Statistically significant positive correlation was documented between the first-day SAA and CRP levels $(p<0.01)$ and between the first-day SAA and CRP levels and Karnofsky scores $(p=0.028$ for SAA, $p=0.034$ for CRP). A statistically significant correlation was also determined between the median values of daily SAA ve CRP levels from the first day of the febrile episode till the twelfth day $(p<0.05)$ (Figures 1 and 2).

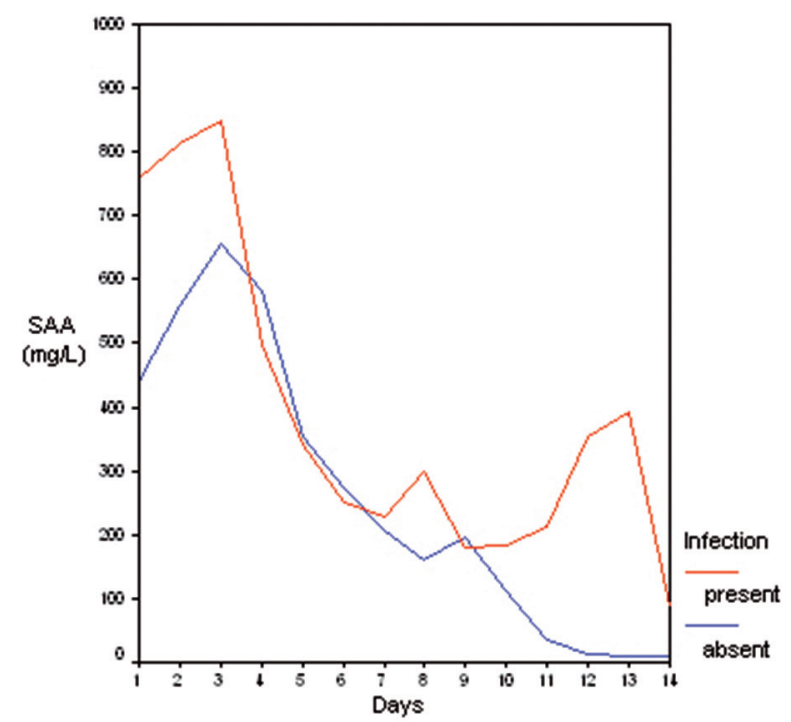

Figure 1. The 14-day course of median SAA levels in cases with documented infection $(\mathrm{BI}, \mathrm{MI}, \mathrm{Cl})$ and in cases without documented infection (FUO).

The sensitivity of SAA level greater than 80 $\mathrm{mg} / \mathrm{L}$ was $100 \%$, the positive (PPV) and the negative (NPV) predictive values for detection of infection were $48 \%$ and $100 \%$, respectively. The specificity of SAA remained low even at cut-off level greter than $200 \mathrm{mg} / \mathrm{L}$. The sensitivity of CRP level greater than $50 \mathrm{mg} / \mathrm{L}$ was $86 \%$, the PPV and the NPV for detection of infection were $47 \%$ and $60 \%$, respectively. The specificity of CRP also remained low (Tables 2 and 3 ). 


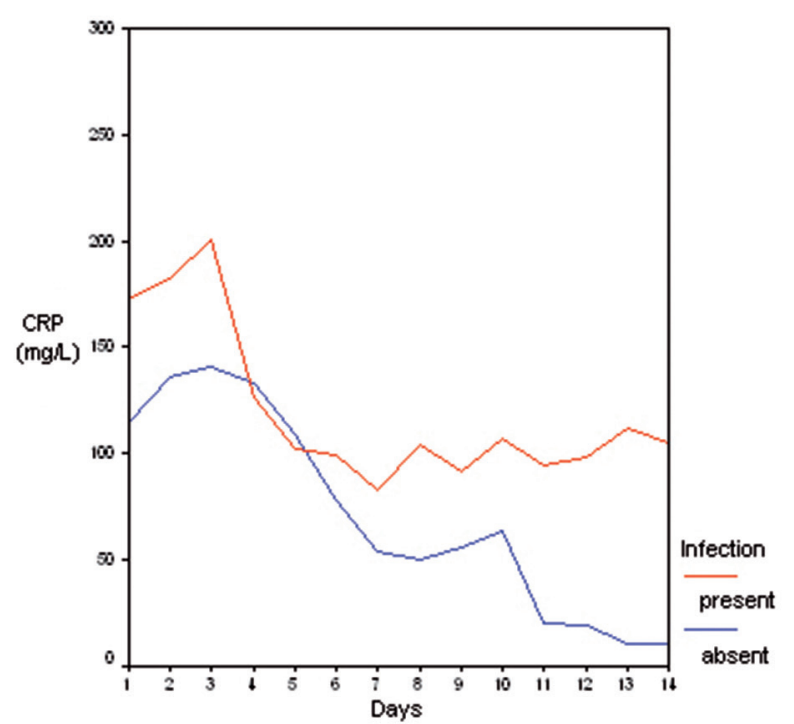

Figure 2. The 14-day course of median CRP levels in cases with documented infection (BI, $\mathrm{MI}, \mathrm{Cl}$ ) and in cases without documented infection (FUO).

Table 2. Sensitivity, specificity, positive and negative predictive values (PPV and NPV) of serum amyloid A (SAA) for detection of infection in patients with FEN

\begin{tabular}{lcccc}
\hline Cut-off level & Sensitivity & Specificity & PPV & NPV \\
\hline$>200 \mathrm{mg} / \mathrm{L}$ & $90 \%$ & $17 \%$ & $49 \%$ & $66 \%$ \\
$>180 \mathrm{mg} / \mathrm{L}$ & $93 \%$ & $11 \%$ & $47 \%$ & $66 \%$ \\
$>80 \mathrm{mg} / \mathrm{L}$ & $100 \%$ & $8 \%$ & $48 \%$ & $100 \%$ \\
\hline
\end{tabular}

PDF: positive predictive value, NPV: negative-predictive value

Table 3. Sensitivity, specificity, positive and negative predictive values ( PPV and NPV) of C-reactive protein (CRP) for detection of infection in patients with FEN

\begin{tabular}{lcccc}
\hline Cut-off level & Sensitivity & Specificity & PPV & NPV \\
\hline$>200 \mathrm{mg} / \mathrm{L}$ & $60 \%$ & $74 \%$ & $66 \%$ & $68 \%$ \\
$>150 \mathrm{mg} / \mathrm{L}$ & $76 \%$ & $45 \%$ & $54 \%$ & $69 \%$ \\
$>100 \mathrm{mg} / \mathrm{L}$ & $86 \%$ & $28 \%$ & $51 \%$ & $71 \%$ \\
$>50 \mathrm{mg} / \mathrm{L}$ & $86 \%$ & $17 \%$ & $47 \%$ & $60 \%$ \\
\hline
\end{tabular}

PDF: positive predictive value, NPV: negative-predictive value

When the predictive values of initial median SAA and CRP levels for the presence of infection (BI, MI and $\mathrm{Cl}$ vs FUO) were examined, statistically significant difference was found only in CRP levels $(p=0.015$ for CRP; $p=0.947$ for SAA). Similar results were found also when the last-day SAA and CRP levels regarding infection were examined $(p=0.054$ for SAA; $p=0.010$ for CRP) (Figures 3 and 4 ). The difference of SAA levels between days was more evident than CRP (c2=186 for SAA, c2 =153 for CRP). ROC curve to determine the accuracy of CRP and SAA in predicting infection was demonstrated in Figure 5. Area under the curve (AUC) for CRP and SAA were $0.72(p=0.003,95 \% \mathrm{Cl}: 0.59-0.86)$ and 0.68 ( $p=0.019,95 \% \mathrm{Cl}: 0.54-0.82$ ), respectively.

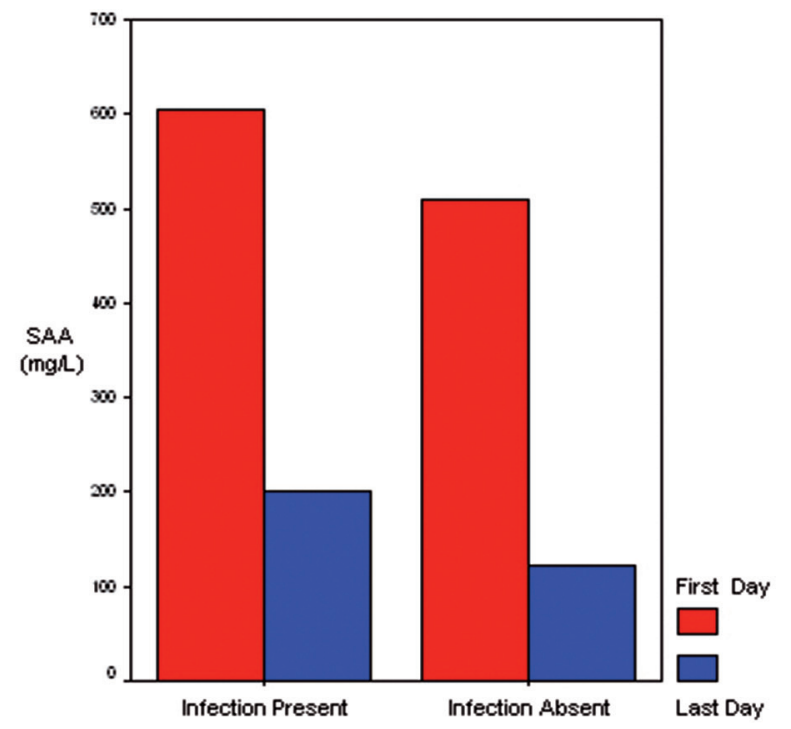

Figure 3. Comparison of the first-day and the last-day median levels of SAA in cases with documented infection $(\mathrm{BI}, \mathrm{MI}, \mathrm{Cl})$ and in cases without documented infection (FUO).

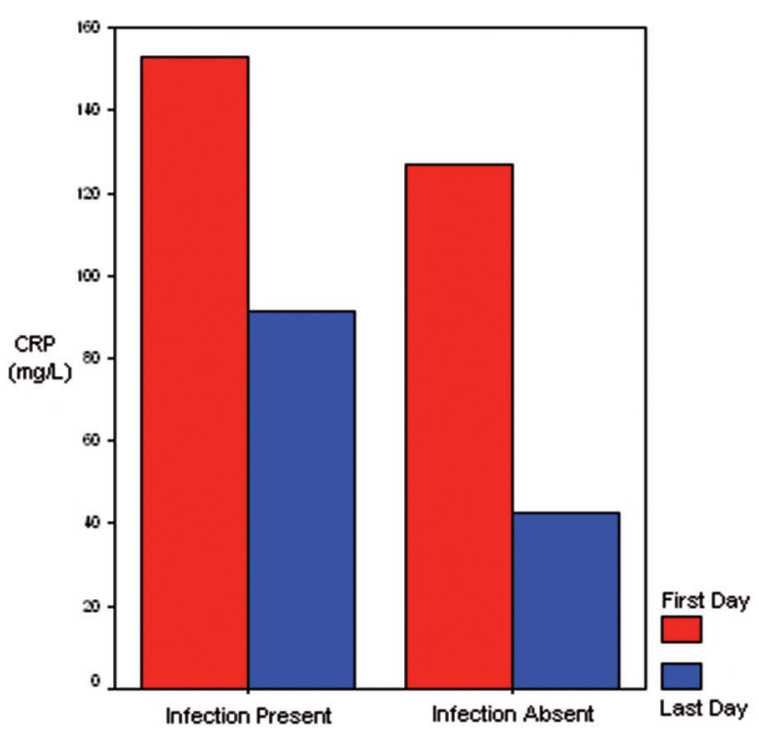

Figure 4. Comparison of the first-day and the last-day median levels of CRP in cases with documented infection $(\mathrm{BI}, \mathrm{MI}, \mathrm{Cl})$ and in cases without documented infection (FUO). 


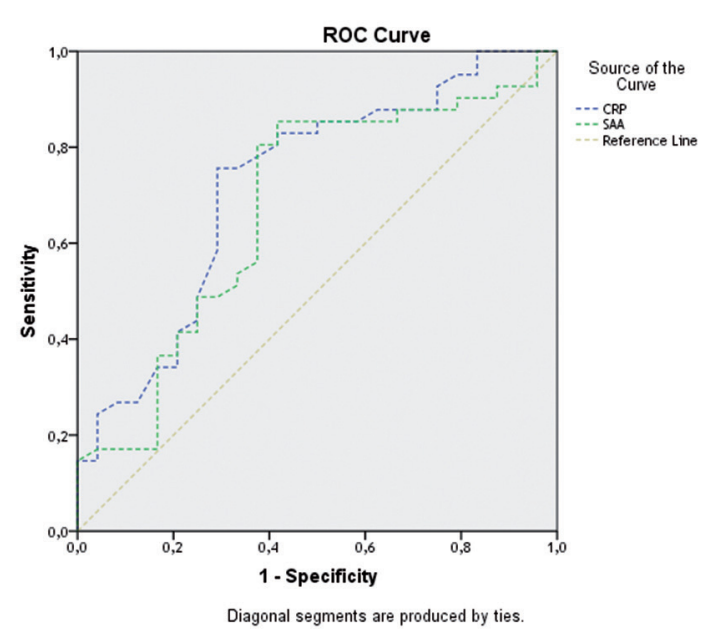

Figure 5. Receiver operating characteristic (ROC) curve to determine the accuracy of CRP and SAA in predicting infection.

\section{DISCUSSION}

In patients with FEN, infection is the most important cause of mortality, fever should be considered as a sign of a life-threatening infection in neutropenic patients until any type of infection is excluded. and those patients should be managed accordingly. The patient who has signs and symptoms consistent with infection should be managed immediately and a number of diagnostic steps should be taken. Inadequate inflammatory response and inapperance of signs and symtoms of infection because of decreased neutrophil count causes a major difficulty in diagnosis. The only sign of infection in patients with severe neutropenia $(P N L<100 / \mathrm{m} 3$ ) is often fever. However, although the physical signs corresponding to the infectious focus are usually absent and the cause of fever is recognised in only $25-30 \%$ of cases in the last $10-15$ years, physical examination should be made thoroughly.

Various markers which may contribute to diagnosis or exclusion of infections in patients with FEN have been investigated for years. An ideal parameter would rise before the documentation of significant microbiologic findings or would direct to further investigations to determine the focus of infection even in nonfebrile patients. Unfortunatelly, none of the proposed parameters has a major clinical relevance in the differential diagnosis of infectious and non-infectious causes of fever in neutropenic patients. Although studies using cytokines which are expensive have been made recently, their practical use seems to be limited. Among these, IL-6, which has been shown to increase earlier and to be a more sensitive marker, its sensitivity to predict bacterial infections for institution of initial therapy remained too low. Moreover, its predictive value and accuracy was equal to that of CRP. ${ }^{18,19}$ It was reported that the CRP levels above $40 \mathrm{mg} / \mathrm{L}$ in febrile neutropenic patients were closely related with infection, the probability of infection increased as it was elevated above $100 \mathrm{mg} / \mathrm{L}$, and the elevation of CRP more than $50 \mathrm{mg} / \mathrm{L}$ within 24 hours follow-up had a positive predictive value of $95 \% .{ }^{20}$ Yonemori et al. showed CRP to be useful to monitor the response to therapy for febrile episodes in neutropenia. However, they failed to show statistically significant differrences in CRP levels between febrile episodes with or without clinically documented infection and with or without bacteremia. ${ }^{21}$

Studies with CRP being more practical and cost-effective than cytokines are accepted as routine follow-up parameters in many centres. CRP level is used as a sensitive inflammation indicator in bacterial infections, but it shows only a minimal increase in acute viral infections. SAA, in contrast to CRP, followed the same elevation trend in both bacterial and viral infections. ${ }^{22}$ SAA has been a useful inflammatory indicator in acute viral infections in which viral isolation is impossible and the differential diagnosis is difficult clinically. ${ }^{23}$ The improvement of infection and the effectiveness of antimicrobial therapy are assessed by rapid decrease in SAA levels. ${ }^{24,25,26}$ It has been reported that levels of both parameters increased in acute phase of infections, decreased in the convalescent phase, and disclosed a clear positive correlation with each other, ${ }^{27}$ similar to our findings in this study. Compared to CRP, five to eleven times more increase was observed in SAA leves, which increased evidently in $98 \%$ of acute phase of viral infections. In contrast to our results, SAA was shown to disappear earlier than CRP. Riikonen et al have shown that the acute phase reactants CRP and SAA were elevated together in most episodes, but neither was definitive in differentiating between the categories of febrile episodes. ${ }^{28}$ SAA was proved to be more sensitive than CRP for the early detection of bacteremia. No normal values of SAA were observed in the group with true bacteremia, as opposed to $32 \%$ of normal CRP values in bacteremia. ${ }^{28}$

In one of our previous studies, we had found the CRP levels in the first 48 hours of FEN episode were significant for prediction of infection $(p=0.001)$ but insignificant for prediction of mortality $(p=0.595){ }^{15}$ Taking these data into consideration, in this study we investigated the change in CRP 
and SAA levels on consecutive days measured by nephelometric immunoassay and we determined a clear correlation between SAA and CRP concordant with data in the literature despite the fact that SAA levels increased more in the first day of FEN episode. Initial (first-day) SAA and CRP levels were insignificant to predict infection and mortality. But a significant decrease in time was evident in all cases. Undetermined probable infections in the group of fever of unknown origin (FUO) could play a role in this consequence. When the initial and the last-day levels were compared, SAA seemed to be more sensitive than CRP. All of these results are consistent with previous data in the literature. The sensitivity and NPV of SAA for detection of infection was high (both are 100\%) at the cutoff level 80 $\mathrm{mg} / \mathrm{L}$ but the specificity of SAA remained low even at cutoff level greater than $200 \mathrm{mg} / \mathrm{L}$. The specificity could increase if dilution procedure was applied in the nephelometric assay (that is to detect the exact levels greater than $200 \mathrm{mg} / \mathrm{L}$ ) but that could not be cost-effective for every patient. The specificity of CRP for detection of infection also remained low. When the variation of SAA and CRP levels on the consecutive days was investigated; it was observed that both parameters had increased more on the second and the third day of the febrile episode than the first day, and decreased progressively later on and this decrease was statistically highly significant (Figures 1 and 2). The difference of SAA levels between days was more evident than CRP. This result may be interpreted as SAA being a better predictor of the level of infection and inflammation and being more sensitive than CRP. AUC on the ROC curve for both CRP and SAA were nearly 0.7 which meant that they were fair tests with some uses in prediction of infection.

The prediction of mortality was not taken into consideration statistically; because of the low number (only 5) of mortal cases and the shortness of the duration of the follow-up. The levels of SAA and CRP in those four patients who died from sepsis were initially higher than the levels in patients who survived. The "prediction of mortality" mentioned as one of the intentions is evidently impossible due to severe underpowering.

According to the literature, predictive values of CRP, proinflammatory cytokines and soluble adhesion molecules seem to be too low to influence initial treatment decisions in patients with neutropenic fever. There were several limitations of the studies such as poor design and small size of the study population. Moreover, studies were heterog- enous with respect to patients involved (children and adults, patients with hematologic malignancy and patients with solid tumors) and the different categories of febrile episodes compared. None of the investigators analyzed cost-effectiveness or impact of serial measurements of these parameters on patients' outcome. Furthermore, at present, no single multicenter trial has been published related to this issue. Therefore, it is difficult to draw general conclusions. More data are necessary to decide on the utility of those parameters in diagnosis of infection in neutropenic fever. Although none of the parameters proposed up to now has gained major clinical significance in diagnosis of etiology of neutropenic fever, SAA and CRP, which are more practical to determine and cheaper than cytokines, are proved once more to be significant parameters in the follow-up of FEN episodes in this study. Moreover, SAA was found to be more sensitive in the presence of infection.

Main weaknesses of our study are disclosed as the following: It has been reported that mortality in patient group with FUO could be significantly decreased by the early institution of broad-spectrum antibiotics. Calculations of sensitivity, specificity, PPV and NPV for detection of infection were presented in Tables 2 and 3 do not include those patients with FUO. In addition, the number of febrile neutropenic episodes is rather small to draw any valuable conclusion. Patients receiving blood-products should be rolled out per the definition by that such products could cause immunological fever. In a significant number of episodes, patients $(47.7 \%)$ were transfused with blood-products during the study period. Itmay have an impact on the results.

\section{CONCLUSION}

Better-designed studies may provide results with higher predictive values with addition of new parameters. The significance of SAA and CRP in prediction of infection may increase with measurement of their levels in neutropenic patients before becoming febrile. In conclusion; despite low predictive values of these parameters in decision of initial antimicrobial therapy in febrile neutropenic patients, they would be helpful in decision of modification and evaluation of response to therapy.

\section{REFERENCES}

1. Quadri TL, Brown AE. Infectious complications in the critically ill patient with cancer. Semin Oncol 2000;27:335-346.

2. Ellis M. Febrile neutropenia. Ann N Y Acad Sci 2008;1138:329350 
3. Freifeld AG, Bow EJ, Sepkowitz KA, et al. Clinical practice guideline for the use of antimicrobial agents in neutropenic patients with cancer: 2010 update by the Infectious Diseases Society of America. Clin Infect Dis 2011;52:e56-e93.

4. Sudhoff T, Giagounidis A, Karthaus M. Evaluation of neutropenic fever: value of serum and plasma parameters in clinical practice. Chemotherapy 2000;46:77-85.

5. Lehrnbecher T, Venzon D, de Haas M, et al. Assessment of measuring circulating levels of interleukin-6, interleukin-8, C-reactive protein, soluble Fc gamma receptor type III, and mannose-binding protein in febrile children with cancer and neutropenia. Clin Infect Dis 1999;29:414-419.

6. Engel A, Steinbach G, Kern P, Kern WV. Diagnostic value of procalcitonin serum levels in neutropenic patients with fever: comparison with interleukin-8. Scand J Infect Dis 1999;31:185-189.

7. Kern WV, Heiss M, Steinbach G. Prediction of gram-negative bacteremia in patients with cancer and febrile neutropenia by means of interleukin-8 levels in serum: targeting empirical monotherapy versus combination therapy. Clin Infect Dis 2001;32:832-835.

8. Giamarellos-Bourboulis EJ, Grecka P, Poulakou G, et al. Assessment of procalcitonin as a diagnostic marker of underlying infection in patients with febrile neutropenia. Clin Infect Dis 2001;32:1718-1725.

9. Uys A, Rapoport BL, Fickl H, et al. Prediction of outcome in cancer patients with febrile neutropenia: comparison of the Multinational Association of Supportive Care in Cancer riskindex score with procalcitonin, C-reactive protein, serum amyloid $\mathrm{A}$, and interleukins-1beta, $-6,-8$ and -10 . Eur $\mathrm{J}$ Cancer Care (Engl) 2007;16:475-483.

10. Persson L, Soderquist B, Engervall $P$, et al. Assessment of systemic inflammation markers to differentiate a stable from a deteriorating clinical course in patients with febrile neutropenia. Eur J Haematol 2005;74:297-303.

11. Wang CS, Sun CF. C-reactive protein and malignancy: clinico-pathological association and therapeutic implication. Chang Gung Med J 2009;32:471-482.

12. Kanoh $\mathrm{Y}, \mathrm{Abe} \mathrm{T}$, Masuda N, Akahoshi T. Progression of nonsmall cell lung cancer: diagnostic and prognostic utility of matrix metalloproteinase-2, C-reactive protein and serum amyloid A. Oncol Rep 2013;29:469-473.

13. Eklund KK, Niemi K, Kovanen PT. Immune functions of serum amyloid A. Crit Rev Immunol 2012;32:335-348.

14. Fischer K, Theil G, Hoda R, Fornara P. Serum amyloid A: a biomarker for renal cancer. Anticancer Res 2012;32:18011804.
15. Gencer S, Salepci T, Ozer S. Evaluation of infectious etiology and prognostic risk factors of febrile episodes in neutropenic cancer patients. J Infect 2003;47:65-72.

16. Hollen PJ, Gralla RJ, Kris MG, et al. Measurement of quality of life in patients with lung cancer in multicenter trials of new therapies. Psychometric assessment of the Lung Cancer Symptom Scale. Cancer 1994;73:2087-2098.

17. Schag CC, Heinrich RL, Ganz PA. Karnofsky performance status revisited: reliability, validity, and guidelines. J Clin Oncol 1984;2:187-193.

18. Karan MA. Predictive value of higher plasma interleukin- 6 levels in patients with febrile neutropenia. Arch Med Res 2002;33:557-561.

19. Engervall P, Granstrom M, Andersson B, Bjorkholm M. Monitoring of endotoxin, interleukin-6 and C-reactive protein serum concentrations in neutropenic patients with fever. Eur $\mathrm{J}$ Haematol 1995;54:226-234.

20. Manian FA. A prospective study of daily measurement of Creactive protein in serum of adults with neutropenia. Clin Infect Dis 1995;21:114-121.

21. Yonemori K, Kanda Y, Yamamoto R, et al. Clinical value of serial measurement of serum C-reactive protein level in neutropenic patients. Leuk Lymphoma 2001;41:607-614.

22. Yamada T. Serum amyloid A (SAA): a concise review of biology, assay methods and clinical usefulness. Clin Chem Lab Med 1999;37:381-388.

23. Schultz DR, Arnold PI. Properties of four acute phase proteins: C-reactive protein, serum amyloid A protein, alpha 1-acid glycoprotein, and fibrinogen. Semin Arthritis Rheum 1990;20:129-147.

24. CasI MT, Sabljar-Matovinovic M, Kovacevic S, et al. Clinical relevance of serum amyloid $A$ protein monitoring in urinary tract infections. Ann Clin Biochem 1993;30 ( Pt 3):272-277.

25. Marhaug G, Permin H, Husby G. Amyloid-related serum protein (SAA) as an indicator of lung infection in cystic fibrosis. Acta Paediatr Scand 1983;72:861-866.

26. Miwata H, Yamada T, Okada M, Kudo T, Kimura H, Morishima T. Serum amyloid A protein in acute viral infections. Arch Dis Child 1993;68:210-214

27. Nakayama T, Sonoda S, Urano T, et al. Monitoring both serum amyloid protein A and C-reactive protein as inflammatory markers in infectious diseases. Clin Chem 1993;39:293-297.

28. Riikonen P, Saarinen UM, Teppo AM, et al. Cytokine and acute-phase reactant levels in serum of children with cancer admitted for fever and neutropenia. J Infect Dis 1992;166:432-436. 